\title{
Economic Barriers to Herbicide-Resistance Management
}

\author{
Terrance M. Hurley and George Frisvold*
}

\begin{abstract}
Herbicide-resistant weeds are the result of evolutionary processes that make it easy to think about the problem from a purely biological perspective. Yet, the act of weed management, guided by human production of food and fiber, drives this biological process. Thus, the problem is socioeconomic as well as biological. The purpose of this article is to explain how well-known socioeconomic phenomena create barriers to herbicide-resistance management and highlight important considerations for knocking down these barriers. The key message is that the multidimensional problem requires a multifaceted approach that recognizes differences among farmers; engages the regulatory, academic, extension, seed and chemical suppliers, and farmer communities; and aligns the diverse interests of the members of these communities with a common goal that benefits all-more sustainable weed management. It also requires an adaptive approach that transitions from moreuniform and costly standards and incentives, which can be effective in the near-term but are unsustainable, to more-targeted and less-costly approaches that are sustainable in the long term.

Key words: Herbicide resistance management, nonmonetary benefits, tragedy of the commons, uncertainty, weed management.
\end{abstract}

Herbicide-resistant weeds are the result of evolutionary processes that make it easy to think about the problem from a purely biological perspective. Yet, the act of weed management, guided by human production of food and fiber, drives this biological process. Thus, weed and herbicide-resistance management (HRM) are inseparably driven by socioeconomic as well as biological factors. Both problems are dynamic because weeds that escape an herbicide's control propagate, often passing on herbicideresistance traits. If the same herbicide is relied on repeatedly and widely, the primary weeds occupying farmers' fields will become resistant to that herbicide. The more effective and widely used the herbicide is, the more rapidly resistance tends to emerge, which creates an inherent tension between what is best for managing weeds and what is best for managing herbicide resistance (HR). Weeds and HR can also move across the landscape because of natural and human-mediated forces, such that HR can emerge even in fields where substantial effort has been devoted to managing it.

The purpose of this article is to explain how wellknown socioeconomic phenomena can create barriers to farmer adoption of HRM practices. By HRM, we mean applying diversified weed-management practices to proactively prevent or delay

DOI: $10.1614 /$ WS-D-15-00046.1

* Professor, Applied Economics, University of Minnesota, 231 Ruttan Hall, St. Paul, MN 55108; Professor, Agricultural and Resource Economics, The University of Arizona, 319 Chávez Building, Tucson, AZ 85721. Corresponding author's E-mail:tmh@umn.edu resistance. Thus, HRM is more than adjusting weed management to the presence of particular resistant weeds once they appear. In this framework, shifting from overuse of an herbicide with one mode of action (MOA) to overuse of an herbicide with a different MOA is not HRM. Rather, HRM is explicitly forward looking, considering how management decisions made today affect the likelihood of resistance in the future.

Broadly speaking, the phenomena we discuss relate to individual farmers, farming communities, and the seed and chemical industry. These broad categories serve to highlight how the goals of HRM can vary across stakeholders, which makes coordination another challenge for HRM. Some considerations for improving coordination to meet this challenge are also highlighted.

A key message is that there are multiple dimensions to the problem of herbicide-resistant weeds. Although several of these dimensions are reasonably well understood when viewed in isolation, less is known about formulating moreintegrative solutions across stakeholders. Still, progress can be made toward addressing the problem by moving forward with what we do know can work in the near term, while learning and adapting to what we discover can also work in the longer term.

\section{Barriers to HRM}

Individual Farmers. Economic factors are often at the forefront in determining what steps farmers 
might take to manage resistance. A four-state survey of cotton (Gossypium hirsutum L.) and soybean [Glycine max (L.) Merr.] consultants found that costs were cited as a reason for farmers not adopting 13 out of 16 different resistance-management practices (Riar et al. 2013). Costs were cited more frequently than any other factor (including overall profitability). Consultants also noted that crop output prices dictated which crops were included in their cropping systems. Weirich et al. (2011) added, "cost or economics was always a prominent concern when farmers were asked about factors involved in considering the implementation of herbicide resistant management practices" ( $\mathrm{p}$. 782). Hurley et al. (2009a) found that best management practices (BMPs) with particularly low adoption rates (cleaning equipment, using herbicides with different modes of action, and using supplemental tillage) were associated with higher weed-management costs.

Although economic factors provide important incentives for farmers, they are not the only motivator. The rapid and widespread adoption of herbicide-tolerant crops, such as Roundup Ready soybean (Monsanto, 800 N. Lindburgh Blvd., St. Louis, MO 63167), reminds researchers that many "nonmonetary" factors are also motivators. Examples drawn from recent literature include simplicity, convenience, flexibility, timing and time, crop safety, family and worker health, water and wildlife quality, consistency of crop protection, yield loss, compatibility with conservation tillage, clean fields, and land stewardship (Bonny 2007; Carpenter and Gianessi 1999; Fernandez-Cornejoet al. 2005; Gardner et al. 2009; Hurley and Mitchell 2014; Hurley et al. 2009b; Marra et al. 2004; Sydorovych and Marra 2008). When exploring many of these factors jointly, Hurley et al. (2009b) and Hurley and Mitchell (2014) found commonalities across crops in terms of the most-important motivators of farmers' weed and insect management decisions (see Figure 1). For example, a higher percentage of farmers rated yield protection, consistent pest control, and family and worker safety as important or very important motivators when compared with cost. A more-detailed factor analysis further discerns human and environmental health and time management concerns as general motivators of herbicide- and insecticide-management decisions.

Human and environmental health concerns pose a barrier to HRM in weed-management systems that rely heavily on glyphosate-tolerant crops because glyphosate is considered safer for human and environmental health than many alternative herbicides (Fernandez-Cornejo et al. 2012; National Research Council 2010). There is also evidence that glyphosate-tolerant crops have facilitated the adoption of conservation tillage, which reduces soil erosion and improves ground- and surface-water quality (National Research Council 2010). Thus, farmers who have strong human and environmental health concerns may be unwilling to incorporate additional herbicides or to include more-intensive tillage into their weed management programs to manage HR.

The past $30 \mathrm{yr}$ have witnessed an interesting trend in U.S. farm size. Average cropland acreage has remained relatively flat, whereas the midpoint (the midpoint of cropland and harvested cropland acres is the farm size at which $50 \%$ of U.S. cropland and harvested cropland is above and $50 \%$ is below) of cropland and harvested cropland acreage has doubled (see Figure 2). What is driving this trend is a bifurcation in farm size, resulting from many small-acreage farms that account for a relatively small share of total production and the fewer, increasingly large-acreage farms that account for a greater share of total production. For these largeacreage farms, being able to perform operations like seed bed preparation, fertilization, planting, pest and disease management, and harvesting, in a timely manner, is critical for success because of the number of acres that must be managed. The Riar et al. (2013) survey of southern U.S. crop consultants found, "Time constraints corresponding to lack of labor or trained employees and large farm sizes are a critical obstacle for the adoption and timely implementation of several HR-BMPs (herbicide-resistance best management practices)" ( $\mathrm{p}$. 793). For example, time constraints were the most frequently noted barrier to cleaning farm equipment to prevent the spread of herbicide-resistant weeds.

Timely management is also critical for the many smaller-acreage farms, but for a different reason. Time savings for these farmers makes off-farm work feasible, so they can supplement lesser farm incomes (Fernandez-Cornejo et al. 2005, 2007). Smale et al. (2012) found that adoption of HR soybeans increased both off-farm work and off-farm income among Bolivian small holders. Thus, current trends in farm size put a premium on weed-management programs that are simple, flexible, convenient, and quick, which is not always consistent with the diverse and more-complex approaches to weed management recommended for HRM (e.g., Norsworthy et al. 2012). 
(a) Herbicide Use

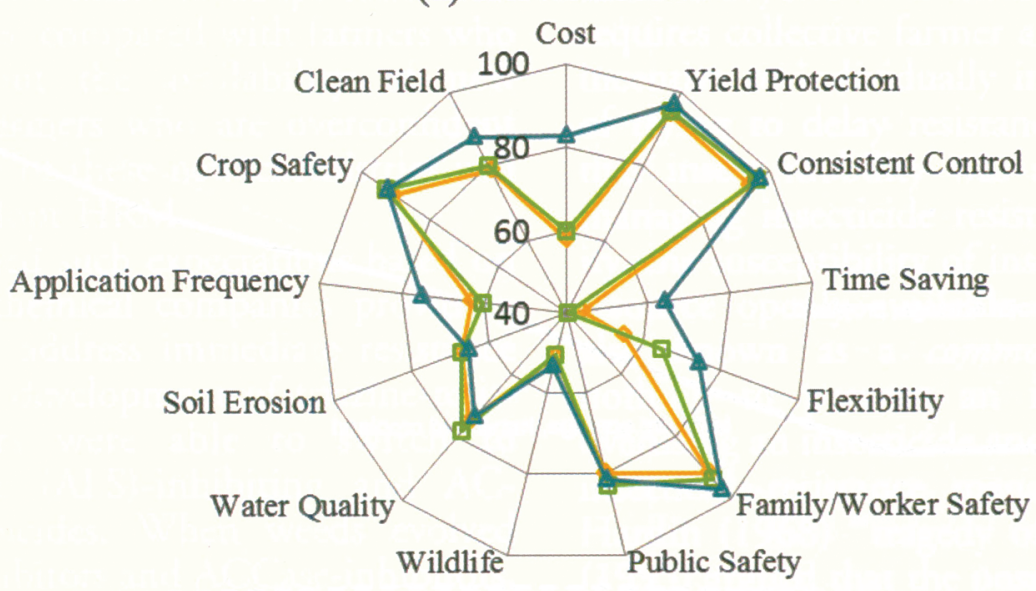

(b) Insecticide Use

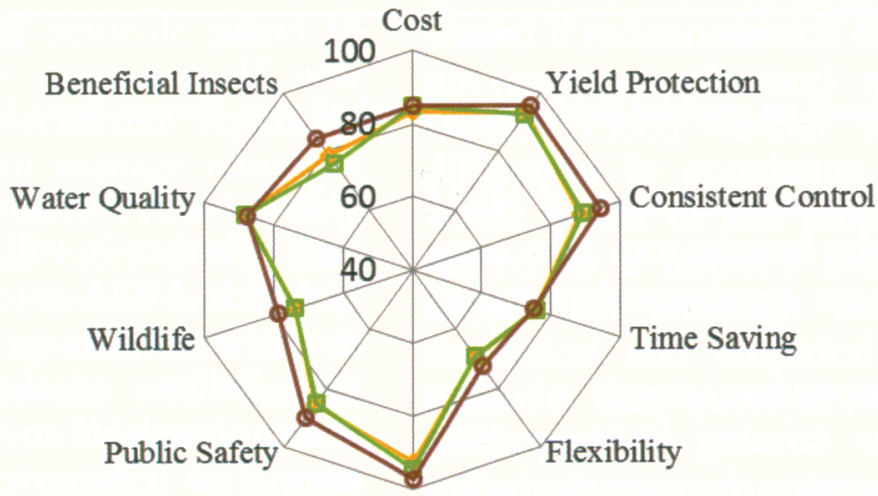

Family/Worker Safety

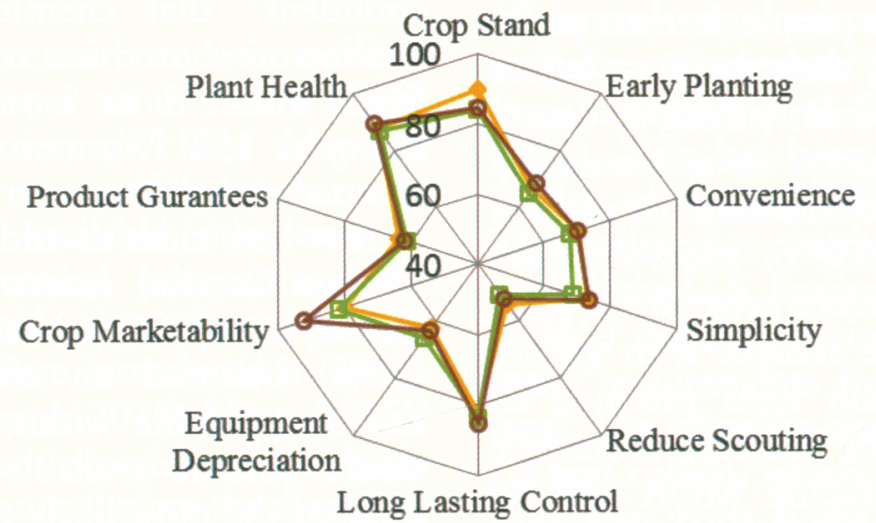

$\rightarrow$ Corn

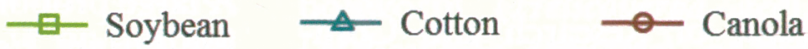

Figure 1. Percentage of farmers indicating an item was an important or very important consideration when choosing (a) herbicides, or (b) insecticides (Source: derived from data reported in Hurley et al. [2009] and Hurley and Mitchell [2014]).

Two other interrelated socioeconomic phenomena that create a barrier to HRM adoption for individual farmers are impatience and uncertainty. There are good economic reasons for impatience. Inflation means the value of a dollar today is less than its value tomorrow. Alternatively, money spent today cannot be invested to earn future interest.
However, impatience is often observed to reach extremes when the potential for gain is immediate. Recent research from the neurosciences suggests that such extreme impatience for immediate rewards may simply be a manifestation of human evolution and a time when our biggest concern was being able to consistently find food (McClure et al. 2004).

Hurley and Frisvold: Barriers to resistance management • 587 


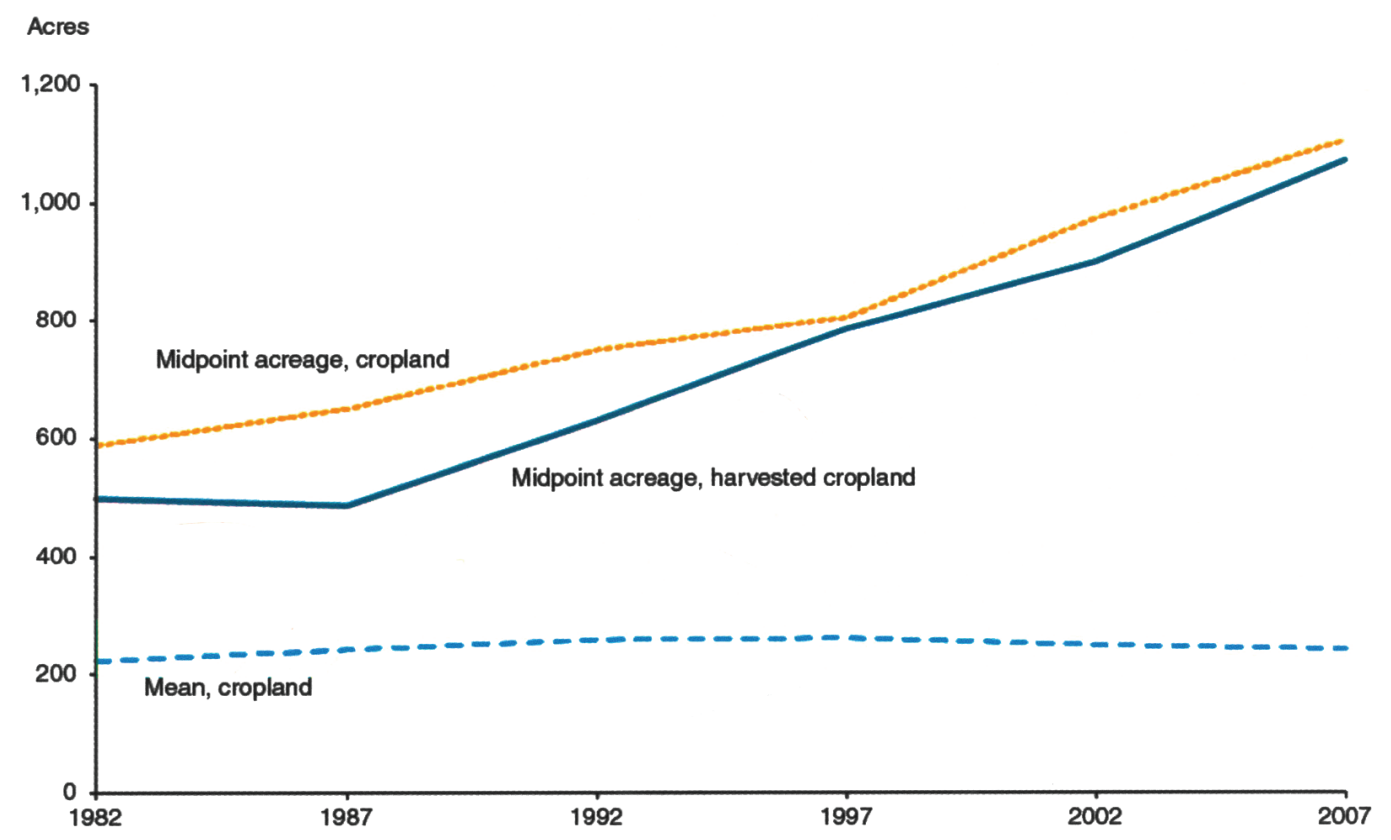

Figure 2. Trend in farm size based on cropland and harvested cropland acres (Source: figure 3, p.8, from MacDonald et al. [2013]).

Regardless of the reason, because the costs of HRM are immediate, whereas the benefits can take some time to emerge, farmers are continuously tempted to delay adoption.

Uncertainty is an important aspect of farm decision making because farming is inextricably linked to biological processes that are not completely understood and is reliant on unpredictable forces like weather. Like most people, farmers prefer to know the consequences of their decisions before making them, which makes them willing to devote resources to reduce uncertainty. It is reasonably straightforward for farmers to calculate the costs of adding an additional herbicide or more-intensive tillage to their weed-management program to delay resistance. Other choices are fraught with greater uncertainty. Will early season rains preclude an application of a PRE herbicide intended to manage HR? Which additional herbicide MOA will be effective at managing HR in the farmer's fields?

David Miller, Director of Research and Commodity Services, Iowa Farm Bureau Federation, succinctly articulated these sentiments at a summit on herbicide-resistant weeds hosted by the National Academies of Science, "'What are the impediments to using best management practices?' I believe the primary impediment is the near-term costs associated with implementation of best management practices to forestall a problem that may or may not develop at some unspecified time in the future" (p. 19, National Research Council 2012).
It is also uncertain how fast HR will emerge or even whether it will emerge before the next new herbicide MOA is discovered. Farmers have less incentive to manage resistance to an herbicide if they believe another new herbicide will soon become available to "solve" their problem. Foresman and Glasgow (2008) reported 92\% of respondents were "somewhat confident" to "very confident" that chemical manufacturers would develop new products to address glyphosate resistance within 3 to 5 yr. Llewellyn et al. (2002) surveyed 132 Western Australian grain farmers about their beliefs concerning the future availability of new herbicides to address rigid ryegrass (Lolium rigidum Gaudin) resistance to acetyl coenzyme $\mathrm{A}$ carboxylase (ACCase)-inhibiting herbicides. Most $(52 \%)$ believed an effective substitute would become available within $6 \mathrm{yr}, 86 \%$ believed one would become available within $10 \mathrm{yr}$, and $21 \%$ believed the most likely time would be 3 yr or less. A large proportion of farmers believed that ACCaseinhibiting herbicides would effectively control weeds on their fields for enough years to provide a bridge to the next new herbicide. Llewellyn et al. (2002) notes that farmers are likely unaware of the number of years it takes to commercially develop a pesticide. This is a process that can take $11 \mathrm{yr}$ in the United States (Ollinger and Fernandez-Cornejo 2010), and Llewellyn et al. (2002) argue that it can take even longer in Australia. In another survey from Australia, Llewellyn et al. (2007) found that farmers who believed new herbicides would be 
available soon were less likely to adopt resistancemanagement practices, compared with farmers who were uncertain about the availability of new chemistries. Thus, farmers who are overconfident about the availability of these new chemistries will be less inclined to adopt HRM.

Farmers have formed such expectations based on the past record of chemical companies providing new chemistries that address immediate resistance problems. Following development of triazine-resistant weeds, farmers were able to switch to acetolactate synthase (ALS)-inhibiting and ACCase-inhibiting herbicides. When weeds evolved resistance to ALS-inhibitors and ACCase-inhibitors, the introduction of glyphosate-resistant crop varieties allowed farmers to switch to glyphosate (Norsworthy et al. 2012). Miranowski and Carlson (1986) considered the role of pesticide prices in farmer decisions to manage resistance. If new pesticides are being commercialized regularly, farmers have little incentive to manage resistance to older pesticides. From the early 1960s to early 1980 s, prices of pesticides rose more slowly than other agricultural inputs did. Frisvold and Reeves (2010) found that this pattern continued up to 2010 for herbicides. Miranowski and Carlson (1986) argued that the failure of pesticide prices to rise relative to other inputs signaled to farmers that resistance was not threatening the abundance of effective pesticides.

Combining relatively certain and immediate HRM costs with uncertainties about future HRM benefits reinforces the barriers to HRM adoption that impatience erects. Farmer confidence that new compounds will become available may well be misplaced, however. Chemical companies have introduced no new herbicide sites of action since HPPD inhibitors, which were introduced in 1982, more than $30 \mathrm{yr}$ ago (Green 2014; Heap 2015). This is a remarkably different experience for farmers compared with the half century before the discovery of HPPD inhibitors when new herbicide sites of action were discovered about every $2 \mathrm{yr}$ on average (Heap 2015).

Farm Community. Miranowksi and Carlson (1986) also demonstrated how an individual farmer has an incentive to manage pesticide resistance when a pest population is relatively immobile. In this case, the farmer can take actions to prevent resistance, weighing costs and benefits, with a certain confidence in the consequences of their HRM decisions. HRM becomes much more challenging if pests are mobile. If farmers believe preventing weed resis- tance is beyond their direct, individual control and requires collective farmer action, they will have less incentive to individually incur the additional costs of trying to delay resistance. Gould (1995) noted that insect mobility was a particular problem in managing insecticide resistance. With high mobility, the susceptibility of insects to an insecticide is a resource openly available to all farmers, which is also known as a common pool resource. With nothing to prevent an individual farmer from overusing an insecticide and depleting susceptibility, insecticide-resistance management could face the Hardin (1968) "tragedy of the commons." Gould (1995) argued that the possibility that some farmers may deplete susceptibility would discourage farmers from incurring costs to manage resistance. Effort and money on resistance management would be wasted if resistant insects from other farms (that did not manage resistance) moved into their fields. Gould (1995) further argued that because of differences in population structure, that resistant weeds would be less mobile and, therefore, more subject to a farmer's individual control. Yet, he added that although this was likely, "detailed theoretical and empirical studies are needed to examine this question more carefully" (Gould 1995, p. 834)

Early literature on the economics of HR tended to assume that individual farmers had a high degree of control over resistance and that common pool resource-management problems were not significant (e.g., Llewellyn et al. 2006; Pannell and Zilberman 2001). This has been reflected in early economic models of optimal HRM (see Renton et al. 2014). The belief that weeds lacked mobility also helps explain the U.S. Environmental Protection Agency's (EPA's) decision to implement resistance-management requirements for plant-incorporated protectants, like (Bacillus thuringiensis) Bt corn (Zea mays L.) and cotton, which control mobile pests like the European corn borer (Ostrinia nubilalis), cotton bollworm (Helicoverpa zea), tobacco budworm (Helicoverpa armigera), or pink bollworm (Pectinophora gossypiella), but not for herbicide-tolerant crops, like Roundup Ready soybean (Frisvold and Reeves 2010).

There is growing evidence suggesting that, in some cases, resistance can move via many routes. These include seed and pollen dispersal by wind, water, animals, farm machinery, and crop residues transported over long distances for livestock feed and other purposes (Busi et al. 2008; Hanson et al., 2009; Hidayat et al. 2006; Liu et al., 2012; Lu et al. 
2007; Michael et al. 2010; Murray et al. 2002; Nordby et al. 2007; Powles and Preston 2006; Rieger et al. 2002; Sosnoskie et al. 2009, 2012). Social scientists now acknowledge that the mobility of herbicide-resistant weeds may be greater than previously thought (Ervin and Jussaume 2014; Frisvold and Reeves 2010; Llewellyn and Pannell 2009; Marsh et al. 2006).

Regardless of whether $\mathrm{HR}$ is a common pool resource-management problem, there is evidence that farmers believe it is. In a survey of Ohio farmers, Wilson et al. (2008) found 97\% attributed weed infestations to wind, whereas $87 \%$ attributed infestations to wildlife, $80 \%$ to birds, and $53 \%$ to waterways. A large share of infestations is also attributed to farm machinery-77\% identified tillage equipment, and $67 \%$ identified harvest equipment. Nearly one in four respondents (23\%) believed that infestations were attributed to poor weed management on neighboring fields. In a survey of Australian farmers, about $70 \%$ of respondents suspected that their neighbors were the ultimate source of herbicide-resistant weeds on their farms (Llewellyn and Allen 2006). Many of these farmers also believed that neighboring farmers would be an important source of resistant weeds coming to their fields in the future.

Seed and Chemical Industry. Trends in the seed and chemical industry have been to integrate more of the weed, insect, and disease management into the seed farmers buy (Shi et al. 2013; Stiegert et al. 2010). This is accomplished by genetically engineering (GE) seed with multiple plant-incorporated protectants (PIPs) or multiple herbicide-tolerance traits: corn with Cry1Ab, Cry1F, Vip3A, mCry3A, and eCry3.1Ab PIP traits; glyphosate- and glufosinate-tolerance traits; and soybean with 2,4-D-, glyphosate-, and glufosinate-tolerance traits (Green 2012; Green et al. 2008). This bundling of traits means that insect, weed, and disease management considerations may enter simultaneously into farmers' seed-choice decisions (Onstad et al. 2011). Alternatively or additionally, seed is increasingly treated with cocktails of insecticides and fungicides, such as the combination of thiamethoxam and abamectin insecticides, and thiabendazole, fludioxonil mefenoxam, and azoxystrobin fungicides currently found in some seed-corn treatments (Munkvold et al. 2014).

Integrating insect, weed, and disease protection into seed has advantages for farmers and the seed and chemical industry. For farmers, using PIPs and seed treatments are simple, convenient, and time saving because insect and disease management are accomplished by simply planting seed. Although farmers must apply herbicides when planting herbicide-tolerant crops, farmers have found weed control with these crops to be simpler, more convenient, more flexible, and to save more time because the herbicides have a broad spectrum of control (Carpenter and Gianessi 1999; FernandezCornejo 2005, 2007). From the chemical and seed industry's perspective, integrating multiple GE traits simplifies and reduces seed production and distribution costs because fewer different types of seed varieties must be produced, inventoried, and marketed (Shi 2009). Integrating multiple GE traits with seed treatments also increases the value of the seed to farmers making it possible for the companies to market the seed for a higher price (Shi and Chavas 2011).

There are disadvantages to this integration too because it can elicit unintended behavioral responses from farmers. For example, if the only PIP corn seed a farmer can purchase to control corn rootworm comes with a glyphosate-tolerance trait, a farmer may be inclined to use glyphosate for weed control even if some other herbicide would be more effective in terms of both weed control and managing HR (National Research Council 2012).

The exclusivity of patents for herbicide compounds can provide an incentive for the patent holder to promote HRM (at least for the life of the patent) to capture higher returns from its research and development. Miranowski and Carlson (1986) provide extensive discussion of the role of patent protection in insecticide-resistance management. It is commonly accepted in the economics literature that exclusive rights over a resource can encourage conservation in fisheries, mining, oil, and forestry (Clark 1976; Dasgupta and Heal 1980; Fisher 1981). For example, during the life of a chemical patent, a monopolist maximizes profits by charging a higher price, which limits sales of the chemical and slows the evolution of resistance. However, once a patent expires, generic versions of the chemical can be produced and sold by many companies, increasing competition. With increased competition, the profitability of producing the chemical decreases, lowering the value of managing resistance, and creating a "tragedy of the commons" for companies. Indeed, when glyphosate went off patent in 2000, generic versions became available at much lower costs, which spurred even greater glyphosate use. It also discouraged use of other, 
more-selective herbicides (Green 2009), reducing the diversity of MOAs in use.

One approach to address glyphosate-resistant weeds is to "stack" multiple resistance traits in individual crop varieties (Green et al. 2008). Companies are developing new crop varieties that combine glyphosate resistance with resistance to herbicides with different MOAs (Green et al. 2008). For example, there are now varieties with glyphosate resistance and resistance to different ALS-inhibiting herbicides. Such stacked varieties will be combined with herbicide blends with different MOAs. Because these blends will be mixtures of currently registered herbicides, they may receive regulatory approval relatively quickly.

Applying herbicide mixtures to crops with multiple $\mathrm{HR}$ can reduce reliance on a single MOA and-in theory-delay resistance. This theoretical delay hinges on two assumptions: resistance to each MOA in a mixture is rare and occurs independently. This means the probability of resistance to two MOAs is the product of two small proportions, which yields an even smaller proportion (Mortensen et al. 2012). However, relying on the rarity of independent events is problematic given many weeds are already resistant to glyphosate, some to ALS inhibitors, and some are resistant to both (e.g., Legleiter and Bradley 2008). Indeed, the list of weeds that are resistant to multiple herbicides continues to grow (Heap 2015; Mortensen 2012).

\section{Toward Multifaceted HRM}

The distinct incentives of farmers, individually and as a group, and the seed and chemical industry create a variety of potential barriers to HRM. Importantly, they create a complex problem, often referred to as a principal-agent problem, in which the goals of the larger community (e.g., moresustainable weed management) are not completely aligned with the goals of individual members of that community (e.g., profitable, simple, convenient, and safe weed management for farmers; and increased product market share for seed and chemical suppliers). The challenge is to develop and implement standards or incentives that align the goals of the community with all of its members. Meeting this challenge requires a multifaceted approach that engages the farmer, agricultural retailer, crop consultant, seed and chemical supplier, and academic, extension, and regulatory com- munities and coordinates all these interests as a common objective.

The principal-agent nature of the problem means that some "authority" must be prepared to take leadership in the design and implementation of the standards or incentives needed to align community interests. This authority could be a government agency (e.g., U.S. Department of Agriculture or the EPA), a farmer organization (e.g., National Cotton Council, United Soybean Board, or National Corn Growers Association), a farmer cooperative (e.g., CHS Inc., 5500 Cenex Drive, Inver Grove Heights, MN 55077), an industry group (e.g., the Herbicide Resistance Action Committee), or public-private partnership between a government agency and farmer or industry group.

When considering what types of standards or incentives are likely to be effective, uniformity should be avoided if possible because it raises costs. For example, Frisvold and Reeves (2008) found that allowing nonuniform requirements for Bt cotton refuges reduced the costs of refuge compliance by up to $38 \%$. Other examples in which additional costs were associated with uniform regulations include Sunding (1996) with insecticides, Yarkin et al. (1994) with fungicides, and Yang et al. (2003) with environmental land retirement. The reason it raises costs more than necessary is due to the heterogeneous nature of agriculture. This includes heterogeneity across farm operations (e.g., soils, topography, climate, enterprise mix, and geopolitical region) and farmers (e.g., experience and plans to remain in farming, tenure on operated land, human and environmental health concerns, timemanagement concerns, impatience, and aversion to uncertainty).

Heterogeneity can also relate to differences in the weeds themselves. Here, the mobility of resistant weed seed and pollen is a critical consideration. In cases in which weed species are not especially mobile, the efficacy of an herbicide is a private resource. Farmers can control the pace of resistance on their own fields by their own actions. One role of extension would then be to educate farmers about the long-run benefits of delaying resistance. Individual farmers can weigh the short-term vs. the long-term consequences of their actions to make resistance-management decisions. In cases in which weeds are highly mobile, however, the ability of individual farmers to delay resistance may be more sensitive to the behavior of neighbors. Here, farmers are more likely to face the "tragedy of the commons" in which farmers perceive their individ-

Hurley and Frisvold: Barriers to resistance management • 591 
ual efforts at resistance management to be futile (Webster and Sosnoskie 2010). This represents a more-challenging case in which policies and incentives would be needed to encourage cooperative resistance-management among groups of farmers.

Additional considerations for designing effective standards are whether they are voluntary or mandatory. To be credible, mandatory standards require the ability to monitor conformance and enforce sanctions for nonconformance. Alternatively, when incentives are employed, they can be either "carrots," subsidies for positive actions, or "sticks," taxes or sanctions for negative actions. As with mandatory standards, effective incentive programs require the ability to monitor the actions upon which the incentives are based, so appropriate subsidies can be paid, taxes collected, or sanctions imposed. To avoid high costs, incentives should not reward-positive actions that would have taken place even without them. Finally, the long-term sustainability of a standard or incentive must be considered. Standards that are expensive to monitor or incentives that pay handsomely for the adoption of HRM practices may be feasible in the short term in response to a crisis, but such high costs are not sustainable in the long term.

\section{Summary and Conclusion}

Weed management and HRM are inextricably linked and driven by socioeconomic, as well as biological, factors. Therefore, strategies to manage HR are bound to fail if they do not account for key socioeconomic phenomena that are driving farmer behavior. The purpose of this article was to provide an overview of well-known economic phenomena that are likely to create barriers to HRM. From an individual farmer perspective, human and environmental health concerns, time management concerns, impatience, and aversion to uncertainty create barriers. From a farm-community perspective, the mobility of weeds and HR because of natural and human-mediated forces can create a "tragedy of the commons" barrier. From a seed and chemical industry perspective, the integration of a farmer's insect-, weed-, and disease-management decisions with their seed decision and competition for increased market share can create barriers.

Which of these potential barriers is the biggest obstacle to HRM is not known. Importantly, which barrier is the biggest obstacle certainly varies across regions of the country, cropping systems, and even individual farmers. Therefore, increasing HRM adoption requires a multifaceted approach that recognizes the differences among farmers; engages the regulatory, academic, extension, seed and chemical supplier, and farmer communities; and aligns the diverse interests of the members of these communities with a common goal that benefits all-more-sustainable weed management. It also requires an adaptive approach that transitions from more-uniform and costly standards and incentives, which are effective in the near term but unsustainable, to more-targeted and less-costly standards and incentives that are sustainable in the long term.

\section{Acknowledgments}

The authors gratefully acknowledge the financial support of the Arizona and Minnesota (MIN-14134) State Agricultural Experiment Stations, the Weed Science Society of America, and the U.S. Department of Agriculture-National Institute of Food and Agriculture (grants 2014-68004-21855 and 2014-67023-21814). All interpretations and conclusions, as well as any errors, are solely those of the authors.

\section{Literature Cited}

Bonny S (2007) Genetically modified glyphosate-tolerant soybean in the USA: adoption factors, impacts and prospects: a review. Agron Sustain Dev 28:21-32

Busi R, Yu Q, Barrett-Lennard R, Powles SB (2008) Long distance pollen-mediated flow of herbicide resistance genes in Lolium rigidum. Theor Appl Genet 117:1281-1290

Carpenter J, Gianessi L (1999) Herbicide tolerant soybeans: why growers are adopting roundup ready varieties. AGBIOFORUM 2:65-72

Clark CW (1976) Mathematical Bioeconomics: The Optimal Control of Renewable Resources. New York: J. Wiley, 365 p

Dasgupta PS, Heal GM (1980) Economic Theory and Exhaustible Resources. New York: Cambridge University Press, $516 \mathrm{p}$

Ervin D, Jussaume R (2014) Integrating social science into managing herbicide-resistant weeds and associated environmental impacts. Weed Sci 62:403-414

Fernandez-Cornejo J, Hallahan C, Nehring R, Wechsler S, Grube A (2012) Conservation tillage, herbicide use, and genetically engineered crops in the United States: the case of soybeans. Agbioforum 15:231-241

Fernandez-Cornejo J, Hendricks C, Mishra A (2005) Technology adoption and off-farm household income: the case of herbicide-tolerant soybeans. J Agric Appl Econ. 37:549-563

Fernandez-Cornejo J, Mishra A, Nehring R, Hendricks C, Southern M, Gregory A (2007) Off-Farm Income, Technology Adoption, and Farm Economic Performance. Washington, DC: USDA, Economic Research Service Report 36,

Fisher AC (1981) Resource and Environmental Economics. New York: Cambridge University Press, $304 \mathrm{p}$ 
Foresman C, Glasgow L (2008) Grower perceptions and experiences with glyphosate resistant weeds. Pest Manag Sci 64:388-391

Frisvold GB, Reeves JM (2008) The costs and benefits of refuge requirements: the case of $\mathrm{Bt}$ cotton. Ecol Econ 65:87-97

Frisvold GB, Reeves JM (2010) Resistance management and sustainable use of agricultural biotechnology. Agbioforum 13:343-359

Gardner JG, Nehring RF, Nelson CH (2009) Genetically modified crops and household labor savings in US crop production. Agbioforum 12:303-312

Gould F (1995) Comparisons between resistance management strategies for insects and weeds. Weed Technol 9:830-839

Green JM (2009) Evolution of glyphosate-resistant crop technology. Weed Sci 57:108-117

Green JM (2012) The benefits of herbicide-resistant crops. Pest Manag Sci 68:1323-1331

Green JM (2014) Current state of herbicides in herbicideresistant crops. Pest Manag Sci 70:1351-1357

Green JM, Hazel CB, Forney DR, Pugh LM (2008) New multiple-herbicide crop resistance and formulation technology to augment the utility of glyphosate. Pest Manag Sci 64:332339

Hanson BD, Shrestha A, Shaner DL (2009) Distribution of glyphosate resistant horseweed (Conyza canadensis) and relationship to cropping systems in the central valley of California. Weed Sci 57:48-53

Hardin G (1968) The tragedy of the commons. Science 162:1243-1248

Heap IM (2015) International Survey of Herbicide Resistant Weeds. http://www.weedscience.org/. Accessed June 6, 2015

Hidayat I, Baker J, Preston C (2006) Pollen-mediated gene flow between paraquat-resistant and susceptible hare barley (Hordeum leporinum). Weed Sci 54:685-689

Hurley TM, Mitchell PD (2014) Value of Insect Pest Management to U.S. and Canadian Corn, Soybean and Canola Farmers. http://growingmatters.org/studies/value/. Accessed March 1, 2015

Hurley TM, Mitchell PD, Frisvold GB (2009a) Weed management costs, weed best management practices, and the Roundup Ready ${ }^{\circledR}$ weed management program. Agbioforum $12: 281-290$

Hurley TM, Mitchell PD, Frisvold GB (2009b) Characteristics of herbicides and weed-management programs most important to corn, cotton, and soybean growers. Agbioforum 12:269280

Llewellyn RS, Lindner RK, Pannell DJ, Powles SB (2002). Resistance and the herbicide resource: perceptions of Western Australian grain growers. Crop Prot 21:1067-1075

Llewellyn RS, Allen DM (2006) Expected mobility of herbicide resistance via weed seeds and pollen in a Western Australian cropping region. Crop Prot 25:520-526

Llewellyn R, Lindner B, Pannell D, Powles S (2006) Adoption of integrated weed management to conserve the herbicide resource: review and framework. Agricultural and Resource Economics, University of Western Australia. Sustainability and Economics in Agriculture SEA Working Paper 00/06, GRDC Project UWA251

Llewellyn RS, Lindner RK, Pannell DJ, Powles SB (2007) Herbicide resistance and the adoption of integrated weed management by Western Australian grain growers. Agric Econ 36:123-130
Llewellyn RS, Pannell DJ (2009) Managing the herbicide resource: an evaluation of extension on management of herbicide-resistant weeds. Agbioforum 12:358-369

Legleiter TR, Bradley KW (2008) Glyphosate and multiple herbicide resistance in common waterhemp (Amaranthus rudis) populations from Missouri. Weed Sci 56:582-587

Liu J, Davis AS, Tranel PJ (2012) Pollen biology and dispersal dynamics in waterhemp (Amaranthus tuberculatus). Weed Sci 60:416-422

Lu Y-Q, Baker J, Preston C (2007) The spread of resistance to acetolactate synthase inhibiting herbicides in a wind borne, self-pollinated weed species Lactuca serriola L. Theor Appl Genet 115:443-450

MacDonald JM, Korb P, Hoppe RA (2013) Farm Size and the Organization of U.S. Crop Farming. Washington, DC: U.S. Department of Agriculture, Economic Research Service ERR152

Marra MC, Piggott NE, Carlson GA (2004) The Net Benefits, Including Convenience, of Roundup Ready ${ }^{\circledR}$ Soybeans: Results from a National Survey (NSF Center for IPM Technical Bulletin 2004-3). Raleigh, NC: Center for Integrated Pest Management, $40 \mathrm{p}$

Marsh SP, Llewellyn RS, Powles SB (2006) Social costs of herbicide resistance: the case of resistance to glyphosate. Paper 25413 in Proceedings of the 50th Annual Conference of the Australian Agricultural and Resource Economics Society. Milwaukee, WI: International Association of Agricultural Economists

McClure SM, Laibson DI, Loewenstein G, Cohen JD (2004) Separate neural systems value immediate and delayed monetary rewards. Science 306:503-507

Michael PJ, Owen MJ, Powles SB (2010) Herbicide-resistant weed seeds contaminate grain sown in the Western Australian grainbelt. Weed Sci 58:466-472

Miranowski JA, Carlson GA (1986) Economic issues in public and private approaches to preserving pest susceptibility. Pages 436-448 in Committee on Strategies for the Management of Pesticide Resistant Pest Populations, Board on Agriculture, National Research Council, eds. Pesticide Resistance: Strategies and Tactics for Management. Washington, DC: National Academy

Mortensen DA, Egan JF, Maxwell BD, Ryan MR, Smith RG (2012) Navigating a critical juncture for sustainable weed management. Bioscience 62:75-84

Munkvold GP, Watrin C, Scheller M, Zeun R, Olaya G (2014) Benefits of chemical seed treatments on crop yield and quality. Pages 89-103 in Global Perspectives on the Health of Seeds and Plant Propagation Material. Dordrecht, the Netherlands: Springer

Murray BG, Morrison IN, Friesen LF (2002) Pollen-mediated gene flow in wild oat. Weed Sci 50:321-325

National Research Council (2010) The Impact of Genetically Engineered Crops on Farm Sustainability in the United States. Washington, DC: The National Academies

National Research Council (2012) National Summit on Strategies to Manage Herbicide-Resistant Weeds: Proceedings of a Symposium. Washington, DC: The National Academies

Nordby D, Harzler R, Bradley K (2007) Biology and management of glyphosate-resistant waterhemp. The Glyphosate, Weeds and Crops Series GWC-13. Purdue Extension

Norsworthy JK, Ward SM, Shaw DR, Llewellyn RS, Nichols RL, Webster TM, Bradley KW, Frisvold G, Powles SB, Burgos NR, Witt WW, Barrett M (2012) Reducing the risks 
of herbicide resistance: best management practices and recommendations. Weed Sci 60(sp1):31-62

Ollinger M, Fernandez-Cornejo J (2010) Regulation and its economic consequences. Pages 338-368 in Rechcigl JE, Rechcigl NA eds. Insect Pest Management: Techniques for Environmental Protection. Boca Raton, FL: CRC

Onstad DW, Mitchell PD, Hurley TM, Lundgren JG, Porter RP, Krupke CH, Spencer JL, DiFonzo CD, Baute TS, Hellmich RL, Buschman LL, Hutchison WD, Tooker JF (2011) Seeds of change: corn seed mixtures for resistance management and integrated pest management. J Econ Entomol 104:343-352

Pannell DJ, Zilberman D (2001) Economic and sociological factors affecting growers' decision making on herbicide resistance. Pages 252-274 in Powles S, Shaner D eds. Herbicide Resistance and World Grains. Boca Raton, FL: CRC

Powles SB, Preston C (2006) Evolved glyphosate resistance in plants: biochemical and genetic basis of resistance. Weed Technol 28:282-289

Renton M, Busi R, Neve P, Thornby D, Vila-Aiub M (2014) Herbicide resistance modelling: past, present and future. Pest Manag Sci 70:1394-1404

Riar DS, Norsworthy JK, Steckel LE, Stephenson DO, Eubank TW, Bond J, Scott RC (2013) Adoption of best management practices for herbicide-resistant weeds in midsouthern United States cotton, rice, and soybean. Weed Technol 27:788-797

Rieger MA, Lamond M, Preston C, Powles SB, Roush RT (2002) Pollen-mediated movement of herbicide resistance between commercial canola fields. Science 296:2386-2388

Shi G (2009) Bundling and licensing of genes in agricultural biotechnology. Am J Agric Econ 91:264-274

Shi G, Chavas JP (2011) The effects of vertical organization on the pricing of differentiated products. J Agric Resour Econ 36:448-464

Shi G, Chavas JP, Lauer J. (2013) Commercialized transgenic traits, maize productivity and yield risk. Nat Biotechnol 31: 111-114

Smale M, Zambrano P, Paz-Ybarnegaray R, Fernández-Montaño W (2012) A case of resistance: herbicide-tolerant soybeans in Bolivia. Agbioforum 15:191-205
Sosnoskie LM, Webster TM, Dales D, Rains GC, Grey TL, Culpepper AS (2009) Pollen grain size, density, and settling velocity for Palmer amaranth (Amaranthus palmeri). Weed Sci 57:404-409

Sosnoskie LM, Webster TM, Kichler JM, MacRae AW, Grey TL, Culpepper AS (2012) Pollen-mediated dispersal of glyphosate-resistance in Palmer amaranth under field conditions. Weed Sci 60:366-373

Stiegert KW, Shi G, Chavas JP (2010) Innovation, integration, and the biotechnology revolution in US seed markets. Choices 25(2)

Sydorovych O, Marra MC (2008) Valuing the changes in herbicide risks resulting from adoption of roundup ready soybeans by U.S. farmers: a revealed preference approach. J Agric Appl Econ 40:777-787

Sunding DL (1996) Measuring the marginal cost of nonuniform environmental regulations. Am J Agric Econ 78:1098-1107

Webster TM, Sosnoskie LM (2010) Loss of glyphosate efficacy: a changing weed spectrum in Georgia cotton. Weed Sci 58:7379

Weirich JW, Shaw DR, Owen MD, Dixon PM, Weller SC, Young BG, Wilson RG, Jordan DL (2011) Benchmark study on glyphosate-resistant cropping systems in the United States, part 5: effects of glyphosate-based weed management programs on farm level profitability. Pest Manag Sci 67:781-784

Wilson RS, Tucker MA, Hooker NH, LeJeune JT, Doohan D (2008) Perceptions and beliefs about weed management: perspectives of Ohio grain and produce farmers. Weed Technol 22:339-350

Yang W, Khanna M, Farnsworth R, Önal H (2003) Integrating economic, environmental and GIS modeling to target cost effective land retirement in multiple watersheds. Ecol Econ 46:249-267

Yarkin C, Sunding D, Zilberman D, Siebert J (1994) Methyl bromide regulation: all crops should not be treated equally. Calif Agric 48:10-15

Received March 24, 2015, and approved July 28, 2015.

Associate editor for this paper: Sarah Ward, Colorado State University. 